(c) American Dairy Science Association, 2006.

\title{
Major Advances in Concentrated and Dry Milk Products, Cheese, and Milk Fat-Based Spreads ${ }^{1}$
}

\author{
D. R. Henning, ${ }^{2}$ R. J. Baer, A. N. Hassan, and R. Dave \\ Minnesota/South Dakota Dairy Foods Research Center, and \\ Dairy Science Department, South Dakota State University, Brookings 57007-0647
}

\begin{abstract}
Advances in dairy foods and dairy foods processing since 1981 have influenced consumers and processors of dairy products. Consumer benefits include dairy products with enhanced nutrition and product functionality for specific applications. Processors convert raw milk to finished product with improved efficiencies and have developed processing technologies to improve traditional products and to introduce new products for expanding the dairy foods market. Membrane processing evolved from a laboratory technique to a major industrial process for milk and whey processing. Ultrafiltration and reverse osmosis have been used extensively in fractionation of milk and whey components. Advances in cheese manufacturing methods have included mechanization of the making process. Membrane processing has allowed uniform composition of the cheese milk and starter cultures have become more predictable. Cheese vats have become larger and enclosed as well as computer controlled. Researchers have learned to control many of the functional properties of cheese by understanding the role of fat and calcium distribution, as bound or unbound, in the cheese matrix. Processed cheese (cheese, foods, spreads, and products) maintain their importance in the industry as many product types can be produced to meet market needs and provide stable products for an extended shelf life. Cheese delivers concentrated nutrients of milk and bioactive peptides to consumers. The technologies for the production of concentrated and dried milk and whey products have not changed greatly in the last $25 \mathrm{yr}$. The size and efficiencies of the equipment have increased. Use of reverse osmosis in place of vacuum condensing has been proposed. Modifying the fatty acid composition of milkfat to alter the nutritional and functional properties of dairy spread has been a focus of
\end{abstract}

Received November 20, 2004.

Accepted August 4, 2005.

${ }^{1}$ Published with the approval of the director of the South Dakota Agricultural Experiment Station as Publication Number 3454 of the Journal Series.

${ }^{2}$ Corresponding author: david.henning@sdstate.edu research in the last 2 decades. Conjugated linoleic acid, which can be increased in milkfat by alteration of the cow's diet, has been reported to have anticancer, antiatherogenic, antidiabetic, and antiobesity effects for human health. Separating milk fat into fractions has been accomplished to provide specific fractions to improve butter spreadability, modulate chocolate meltability, and provide texture for low-fat cheeses.

Key words: membrane processing, cheese, milk fatbased spread, concentrated and dried milk product

\section{MEMBRANE TECHNOLOGY FOR DAIRY PROCESSING}

During the past $25 \mathrm{yr}$, dairy products and dairy processing have seen many changes. The change that has influenced the industry most is the development of membrane technology by early work conducted at research laboratories in France, Hungary, the United States, and Australia; the technology has gone from specialized laboratory procedures to industrial applications. Some of the pioneering researchers in membrane applications for dairy products include Maubois, Cheryan, Horton, Renner, and Kosikowski. The dairy foods industry has contributed the greatest advances in application research for membrane processing. Separation of 2 or more components of different sizes in a fluid feed stream is accomplished with membranes. The components in the fluid stream could be dissolved solutes as well as particulates. The separation technologies using membranes in the dairy industry include microfiltration, ultrafiltration, nanofiltration, and reverse osmosis (RO). Current and new applications of these technologies in the dairy industry include:

1. Processing of whey to concentrate whey proteins and lactose, to separate whey fractions, and to prepare whey protein hydrolysates for food and pharmaceutical uses.

2. Fractionation of milk proteins for specific uses.

3. Fractionation of globular milk fat to change texture and yield of dairy products.

4. Removal of bacterial spores and microorganisms from milk for cheese making. 
5. Recovery of fat from processing waters.

6. On-farm UF of raw milk to reduce cost of shipping the protein rich retentate for further manufacturing. The permeate can be used for animal feed on the farm.

7. Production of high solids dairy products, including semisoft and hard cheeses as well as cheese base for processing.

8. Production of new products from milk. Both retentate and permeate streams can be used to prepare unique products with functional properties not available from other methods of milk fractionation, especially those methods employing phase changes caused by heating.

9. Separation of human proteins (such as lysozyme) for direct medical or pharmaceutical properties from the milk of transgenic animals.

10. Removal of microorganisms and particulates from brine solutions.

11. Purification of cleaning solutions, including caustic and other chemical solutions, by removing colloidal materials and product particles.

Membrane processing systems are engineered for specific applications by manufacturers depending upon the needs of the user. Types of membrane configurations available include tubular, hollow fiber, spiral wound, and plate and frame. Materials used to construct membranes have evolved from cellulose acetate to polysulfone, metallic (zirconium oxide backed with carbon, stainless steel, and alumina), and ceramic.

Metallic and ceramic membranes can tolerate a wide range of $\mathrm{pH}$, sanitation chemicals, high heat, and high operating pressures. Though more costly than polysulfone membranes, the ceramic and metallic membranes can concentrate the volumes of whole milk and skim milk by 7 - and 10 -fold, respectively. The life of the metallic and ceramic membranes can be 5 to $6 \mathrm{yr}$, whereas the polysulfone membranes may last for $1 \mathrm{yr}$.

Membrane technologies (Figure 1) have been described by Cheryan as follows:

"In its ideal definition, reverse osmosis retains all components other than the solvent (e.g., water) itself, while ultrafiltration retains only macromolecules or particles larger than about $10,200 \AA$ (about 0.001 to $0.02 \mu \mathrm{m}$ ). Microfiltration, on the other hand, is designed to retain particles in the "micron" range; that is, suspended particles in the range of $0.10 \mu \mathrm{m}$ to about $5 \mu \mathrm{m}$ (particles larger than 5 to $10 \mu \mathrm{m}$ are better separated using conventional cake filtration methods). Thus, in its broadest sense, reverse osmosis is essentially considered to be a dewatering technique, while ultrafiltration can be looked at as a method for simultaneously purifying, concentrating, and fractionating macromolecules
Membrane Separations

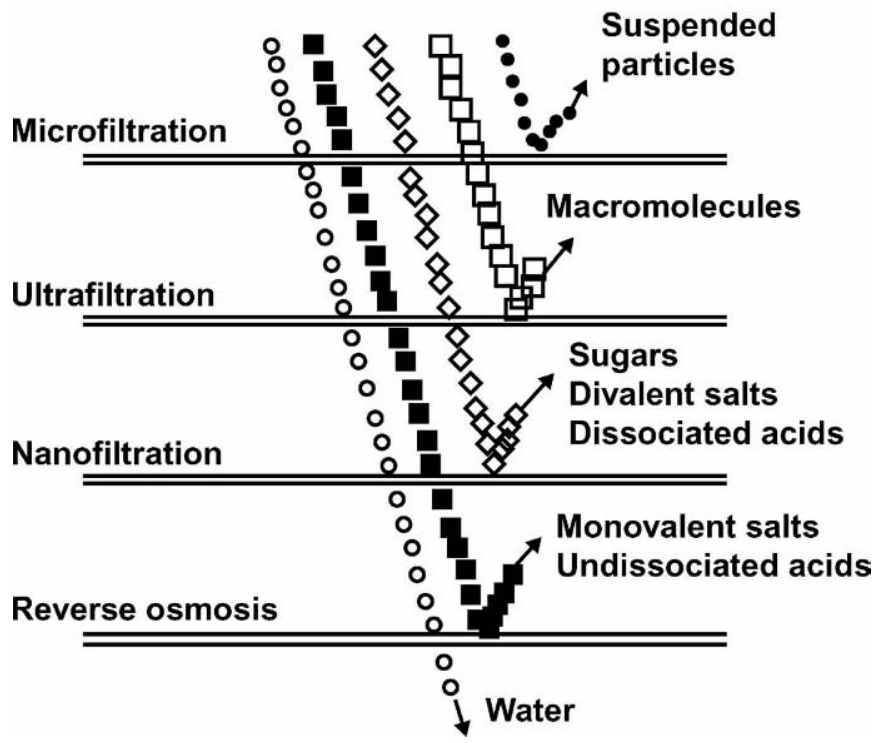

Figure 1. Schematic presentation of membrane separation technologies (reproduced with permission from Technomic Publishing Company, Lancaster, PA).

or fine colloidal suspensions. Nanofiltration is a newer process that uses charged membranes with pores that are larger than those of RO membranes, but too small to allow permeation of many organic compounds such as sugars."

\section{Cheese: Manufacturing Methods, Functionality, Processed Cheese Products, and Nutritional Aspects}

Fermented milk products have been produced and consumed since ancient times. The exact origin(s) of the making of these products is difficult to establish, but it could date back to the times when humans changed from being food gatherers to food producers. Cheese is one such popular fermented milk product, made throughout the world in hundreds of varieties. The United States alone accounts for more than $30 \%$ of the world's cheese production, with the annual production of about 8.6 billion lbs, and about one-third of the milk produced used to make cheese.

Technological advancements led to the evolution of cheese making as a science, which aided in the commercialization of the product. The key scientific advancements in cheese making are in the isolation and characterization of the principal constituents of milk, microbiology of raw milk and treatments, elucidation of the mechanism of coagulation, characterization of the maturation of cheese, and mechanization of cheese product 
lines. These advancements have enabled production of cheese with desired functionality and nutritional value. Recent marketing trends indicate a worldwide increase in production of cheese, which is mainly due to its delicate flavor, functional properties, and long shelf life even in a tropical climate.

Manufacturing Methods. The main step in cheese making is the coagulation of casein micelles by 3 possible methods: limited proteolysis using enzymes, acidification by a starter culture or addition of acids, and heat treatment, or by a combination of these 3 methods. This coagulation results in the formation of a weak gel mass that is then subjected to various treatments (cutting, cooking, cheddaring, etc.) to form a fresh green curd. Treatments and their intensity may vary depending upon the cheese variety and the desired specific functionality in the resulting cheese. For all types of cheeses, manufacturing methodology is all about managing 5 key factors: milk composition, rate and extent of acid development, moisture content, curd manipulation, and ripening conditions. In-depth study of these factors enabled the mechanization of the process and continuous production of different cheese varieties with uniform quality in the same plant. Leaders in these studies include Fox, Kosikowski and Mistry, Lucey, Barbano, McMahon, McSweeney, Olson, and Mann. Innovative technologies such as UF have also attracted the attention of the researchers, mainly because of the potential to increase the yield through the recovery of whey proteins. Ultrafiltration in cheese making can be classified in 3 categories: low concentration factor (up to $1.5 \times)$, medium concentration factor ( 2 to $6 \times$ ), and high concentration factor $(\sim 7 \times)$. However, curd cutting and handling becomes difficult and yield losses increase with increasing concentration of milk solids. The technology has been successfully used for the commercial production of Feta, fresh acid-curd varieties, and moldripened cheeses.

Functionality. In the United States, a large proportion of all cheese is used as an ingredient in different food applications; in most of the applications, cheese functionality is the major criterion for the selection of cheese variety. This requirement of different functional properties for different uses has led to the development of different varieties of cheese. Some important functional properties of cheese are flavor, shreddability, meltability, oiling-off, stretchability, viscosity, and spreadability. The functional properties of cheese depend on milk quality, processing methodology, and final composition. Effects of different culture type, cooking temperature, milk type, moisture content, and storage time on functionality have been extensively studied for different cheese varieties. It has long been recognized that $\mathrm{pH}$, temperature, calcium content, and proteolysis play an important role in determining the functional properties of cheese. Increase in moisture content results in weakening of the rigidity as the volume fraction of protein decreases. There are mixed reports about the effect of fat content on the functionality of cheese. With the increase in fat content, the casein network becomes less dense and, as a result, cheese will stretch and melt at a much faster rate at lower temperatures. However, certain reports consider fat as an inert filling material between aggregates of casein molecules, unless milk is homogenized. Cheese $\mathrm{pH}$ and mineral content have a major impact on cheese functionality. Different manufacturing methodologies result in cheese varieties with different mineral profiles, and it was observed that the proportion of undissolved calcium associated with casein particles in cheese was more important than the total calcium content for cheese functionality. It has been suggested that the texture of Cheddar and Mozzarella cheese may be more dependent on $\mathrm{pH}$ than any other single factor due to its effect on the extent of demineralization in cheese. Proteolytic changes occurring during ripening also affect functionality to a great extent. These changes depend on proteolytic activity of starter organisms and that of residual coagulants. Several studies have been done establishing the specific proteolytic effects of different starters and coagulants.

Processed Cheese Products. Although changing food habits and increasing consumption of pizza-type products have led to a tremendous increase in the demand for the pasta filata type of cheese, processed cheese has maintained its popularity as an important cheese product. Its excellent shelf life over a wide range of temperatures makes it useful in tropical climates. Processed cheese is made by blending different types of natural cheeses with different degree of ripening and nondairy ingredients such as emulsifiers and certain salts. A typical manufacturing protocol involves formulation of blend, shredding/comminuting of cheese and optional ingredients, processing of the blend, and optional homogenization of hot molten blend before cooling and packaging. According to their characteristics, processed cheese products can be classified in 4 different groups: processed cheese (natural cheese, emulsifiers, salt, and coloring); processed cheese food (processed cheese plus optional ingredients including skim milk, whey, milk, cream, albumin, skim milk cheese, and organic acids); processed cheese spread (processed cheese food plus gums for water retention) and processed cheese analogues (sodium caseinate, calcium caseinate, suitable vegetable fats such as soybean and coconut fat, emulsifying agent, salt, and artificial flavor). The major principles for the manufacture of processed cheese involve calcium sequestration, $\mathrm{pH}$ displacement and stabilization, para-casein dispersion, 
water binding, and emulsification. Effects of various manufacturing processes and ingredients on processed cheese characteristics have been studied thoroughly. Several recent patents on processed cheese cover different manufacturing processes. A process was developed for continuous manufacture of processed cheese that involved the production of a powdered milk protein concentrate converted into a desired cheese product without the fermentation, enzymatic treatment, or the separation of curd and whey. A novel product was developed by Mann with natural cheese flavor and a soft, elastic texture. Substitution of sweet cream buttermilk for the water required in standardizing the moisture content of processed cheese spread resulted in a significant increase of yield without any adverse effects on sensory properties. However, some studies showed harder body and higher apparent viscosity with the addition of buttermilk.

Nutritional Aspects of Cheese. Cheese contains a high concentration of essential nutrients relative to its energy content. Its nutritional profile may vary with the type of milk used, the type of starter cultures used, method of manufacture, and ripening conditions. Cheese proteins (mainly caseins) are low in sulfur-containing amino acids and, therefore, the nutritional value of cheese protein is a little lower than that of total milk protein. Its essential amino acid index varies between 91 and 97 if total milk protein is considered at 100. Ultrafiltration of milk before cheese making could be exploited to trap whey proteins to increase nutritional value of cheese proteins. A progressive breakdown of casein during ripening also increases its digestibility.

Fat content is essential in cheese for a wide range of functional properties and from the nutritional viewpoint, cheese is a potentially significant source of both total and saturated fat. Reduction in fat content adversely affects flavor and rheology of cheeses. Studies to improve functional properties of low-fat cheeses and suggested process modifications include manipulation of curd handling, use of exopolysaccharide-producing starters, and addition of stabilizing and emulsifying ingredients.

Cheese is a good source of fat-soluble vitamins and certain trace minerals, in particular calcium, phosphorus, and magnesium. However, their levels vary with the type of cheese and the manufacturing method adopted. A significant number of studies have been conducted on the cariostatic effects of cheese, which support the idea of cheese consumption as an anticaries measure. However, more research is necessary to define the precise mechanism(s) involved in the cariostatic effects of cheese.
Cheese is also a rich source of bioactive peptides, which are associated with lowering hypertension and cholesterol, stimulation of the immune system, and influencing the central and peripheral nervous system. Several studies have reported isolation of such bioactive peptides from cheese and other milk products. Another nutritional improvement in cheese making is the manufacture of low-cholesterol cheese. The methods suggested for its production include substitution of vegetable oil for milkfat, or the use of cholesterol-reduced milk fat made by steam-stripping, or adsorption on to beta cyclodextrin. However, reduction in cholesterol level by such methods resulted in significant alteration in the functionality of the product. Conjugated linoleic acid (CLA) content of cheese has also attracted research interest because of potential anticarcinogenic benefits. Average CLA content in cheese is 0.5 to $1.7 \mathrm{~g} / 100 \mathrm{~g}$ of total fatty acids, and it remains unaffected by different processing treatments and types of starters. In recent years, attempts have been made to manufacture cheeses with probiotic bacteria to capitalize on the huge success of probiotic, fermented products in Europe and the Asia-Pacific region.

\section{Dry Whole and Nonfat Milk and Dry Whey Products}

Drying. The basic operations in the production of milk powder are evaporation and drying. The scientific background of both operations is reported in detail in the literature. Milk is commonly dried by application of either roller or spray drying. In spray drying, the concentrated liquid milk is transformed into dried powder by spraying it into a controlled flow of hot air within the drying chamber. The large surface area of the spray droplets provides for the high evaporation rate. The principle of roller drying is that preconcentrated milk is dried on the surface of a hot drum. As the water evaporates, the thin, dried milk layer is removed from the drum by a scraper.

Spray Drying. Spray drying in the dairy industry can be traced back more than $170 \mathrm{yr}$. However, the first real breakthrough in this industry took place after the introduction of the nozzle and rotary atomizers in the 1910s. Since then, developments have taken place in system components and design and many sophisticated systems are currently available.

The ambient air is filtered to remove airborne particles and combustible materials and then heated to the desired temperature. The concentrate is dispersed into a large number of small droplets by either a rotary (wheel) or a pressure nozzle atomizer. Rotary atomizers were developed and used in Europe whereas pressure atomizers originated in North America. Most dryers are now designed for both types of atomizers to achieve 
flexibility in powder production. Multinozzle systems are also used. In such systems, overlapping of dispersed milk paths leads to agglomeration. Special pressure nozzle atomization of milk has been developed in Japan. This atomizer has an extra wide orifice and the ratio of nozzle length to diameter is relatively low. This modification allows higher flow rates, lower nozzle pressure, and wider spray angle. Milk droplets with uniform dimensions are also produced by creating a sonic field at a constant frequency in the vicinity of the atomizer.

The atomized liquid is mixed with the hot air in the drying chamber. Various drying chamber types are used for milk drying. Referring to the airflow, 2 types of chambers are used, the vertical and horizontal (box) designs. The conical-shaped ceiling of the cylindrical chamber is most commonly used to comply with safety requirements and because of its good pressure shock resistance. The bottom of the chamber can be flat, requiring a mechanical device to remove the powder from the chamber, or conical, enabling powder removal by gravity. The horizontal chamber requires a mechanical device, scraper, or screw conveyor for powder removal. The simplest type of installation is the single-stage system. All chamber types can be used with this system, which may or may not include cooling. Pneumatic conveying or a fluid bed system can be used with the singlestage installation. Two-stage drying systems have also been developed. In such systems, the powder is discharged from the chamber at $5 \%$ moisture into a vibrating fluid bed dryer and cooler. The powder is fluidized by the air in the fluid bed and dried to its final moisture level in the first section of the bed then cooled in the second section. Most developments in the spray-drying systems involved modifications in the drying chamber. The most modern chambers are designed to discharge the powder without mechanical means and to allow its partial separation from the exhaust air. This involves integration of a static fluid bed or a conveying belt (each accommodates the second drying stage) inside the chamber. Three-stage drying was introduced to further increase the thermal efficiency of the drying process. This system contains, in addition to the integrated fluid bed, an external fluid bed in which the final drying and cooling take place. The advantages of the multistage systems are cost reduction and improved product quality. Modifications of the basic systems can be made to accomplish specific product goals. A spray dryer with an after-crystallization belt is used for the production of noncaking whey powder. In this installation, a crystallization belt creates further crystallization for the moist powder (10 to $14 \%$ moisture) leaving the chamber. The belt can be bypassed to produce milk powder.

Powder is recovered from the exhaust air using a cyclone separator, bag filter, or wet scrubber. The pow- der is separated in the cyclone by centrifugal force. A battery of smaller cyclones rather than large ones is used to increase the separation efficiency. A secondary separator (bag filter or wet scrubber) is usually used after the cyclones to meet the environmental rules. In the bag filters, powder is separated from the air by filter bags, which contain weaves that are smaller than the powder particles. Powder is separated from the air in the wet scrubber by washing the laden air with sprayed liquid. The washing liquid is then separated from the clean air in a cyclone-like separator.

Powders with small particles tend to form lumps when mixed with water. Agglomerated powder (powder with porous clusters of single particles) is easier to disperse and dissolve (instant powder). The agglomeration can take place during the drying process (straightthrough) or after drying (rewet). Agglomeration is initiated in the atomizer cloud where collisions between droplets and dry particles take place. Fines separated by the cyclone can be directed into the atomizing zone to form such agglomerates. Usually, a sticky product leaves the chamber with moisture 6 to $7 \%$ higher than the desired moisture, which is attained during the second drying and agglomeration stage in the fluid bed dryer. The vibrating fluid bed is divided into several sections when used in the rewetting process, in which the binder liquid (usually water) is sprayed over the fluidized layer in the first section, then the excess water is removed and powder is cooled in the following stages. Fluid beds integrated into the drying chamber are also used in the agglomeration process. In this case, final drying and cooling are done in an external fluid bed. Classification of particle size occurs in the fluid bed to produce powder with even particle sizes. The agglomeration can take place in an integrated belt dryer (Filtermat) in which a conveyor belt is used.

The whole milk powder is treated with lecithin as a wetting agent at the level of 0.2 to $0.5 \%$ to reduce the amount of free oil, which causes oxidized flavor and flowability deterioration. The lecithination can be an integrated part of the spray drying installation or a separate process.

Roller Drying. The use of roller drying is limited to some special applications such as the production of confectioneries, bakery products, and feed blend. In the roller dryer, a single roller or double roller system is used. In addition to the conventional top fed system, a spray film feed system is also used with the roller dryers. In this system, the concentrate is sprayed onto the surface of the drum by spray nozzles. Some of the problems associated with using a high drying temperature in the roller drying can be eliminated by vacuumroller drying. In a vacuum dryer, milk drying takes place at a temperature as low as $60^{\circ} \mathrm{C}$. Dried whey 
produced by a double roller can be cooled in a fluidized bed cooler. Another modification utilizes an air permeable conveyor belt to cool hygroscopic products such as acid whey.

Developments in Dried Dairy Products. The current challenges in the powder industry are the development of specialty products and maximizing the installation capacity. To achieve the highest capacity, minimum fouling of equipment, reducing product losses, and reduction of energy consumption should be addressed. Different dried dairy products have been developed. Drying skim milk concentrate blended with anhydrous milk fat provides an alternative approach to whole milk powder manufacture. A suggested alternative is based on spray drying the high fat base and simultaneously feeding the skim milk powder into the drying chamber. Fat-filled milk powder is based on skim milk and vegetable or animal fat. This product might contain other additives such as emulsifiers, stabilizers, flavoring, and coloring agents. Spray-dried milk powder containing high free-fat contents, suitable for the chocolate industry, can be produced. The production of this type of milk powder involves simultaneous atomization of 2 feeds, a skim milk concentrate containing precrystallized lactose and cream. Precrystallization is not used in making milk powder unless high free fat is desirable. On the other hand, the production of noncaking whey powder requires efficient precrystallization. High quality, noncaking whey powder is produced using the crystallization belt dryer. A short residence time on this belt allows further lactose crystallization and improves the quality of the whey product. Whey powder containing low levels of lactose is produced by enzymatic hydrolysis. This product is used as an ice cream sweetener. Crystallization is not required and only special dryers with integrated belts (Filtermat) can be used to produce this type of powder because of its extremely high hygroscopicity.

Coffee whiteners were developed several decades ago. The ongoing product development involves the production of dairy-based whiteners without the whey protein that is responsible for sediment formation. The instant properties of coffee whiteners at cold temperatures have been improved with the lecithin treatment. Whey protein concentrate (WPC) is used as an ingredient in baby foods and other food formulas. The combination of UF and diafiltration leads to WPC with up to $99 \%$ protein. Reverse osmosis is also used to concentrate whey before drying. Demineralization of whey involving deacidification is carried out by electrodialysis or ion exchange. To produce demineralized and delactosed WPC, crystallization and separation of lactose are done before demineralization. The delactosed and demineralized whey is evaporated and dried to produce whey protein powder. Refined lactose containing $99 \%$ lactose is used in baby foods, candy, bakery products, sauces, and dressing. The production involves dissolving crude lactose crystals (obtained by centrifugation of crystallized whey) in hot water and precipitating impurities using high heat, active carbon, and acids. The pure lactose solution is evaporated and dried.

Dehydrated cheeses are used as industrial ingredients. They have several advantages over natural cheeses as they are more easily blended and have a longer shelf life with greater diversity of flavor and functional characteristics. The types of dehydrated cheese include dried grated cheese, natural cheese powders, extended cheese powder, and dried enzyme modified cheeses. Production of dried cheese involves grinding hard cheese and drying on a fluidized bed. Ingredients used in making cheese powder include cheese, water, emulsifying salts, and other ingredients such as stabilizers, milk solids, colors, antioxidants, and flavors. Cheese slurry produced by heating and shearing the cheese blend is homogenized and dried using spray drying to produce cheese powder. Enzyme-modified cheeses are cheese curds that are modified through the addition of water, enzymes, starter culture, or other ingredients to accelerate the development of flavor in the matured natural cheese varieties. Enzyme-modified cheese curd is pasteurized and dried.

In addition to the 4 conventional casein products (lactic casein, mineral acid casein, rennet casein, and caseinate), new products containing whey proteins have been developed. High milk protein powder was produced using UF and diafiltration followed by spraydrying at low temperatures $\left(120\right.$ to $125^{\circ} \mathrm{C}$ inlet air temperature and 75 to $80^{\circ} \mathrm{C}$ outlet air temperature). The powder contained about $85 \%$ protein.

Functional Properties of Milk Protein Powders and Their Uses. The functional properties of milk proteins in food products are the result of the intrinsic properties of native proteins such as their amino acid composition and sequence, molecular weight, charge, hydrophobicity, and the protein configuration plus a number of extrinsic factors. The extrinsic factors include temperature, $\mathrm{pH}$, salts, and concentration. In addition, processing techniques such as homogenization, heat treatment, freezing, concentration, and drying will also affect the functionality of milk proteins in foods. Understanding factors affecting the functional properties of milk proteins led to the production of protein products tailored for specific applications. Several types of new food products with varied structures have been developed based on heat-induced changes of milk proteins. Products simulating cheese, meat, and confectionary are produced from heat-treatment model systems containing different protein products, fat, and other dairy and nondairy solids. Rennet casein is mixed 
with vegetable oil, emulsifying salts, food grade acid, and water and cooked to produce cheese products similar to the natural types. Acid casein and caseinates are used in making baked products and cereal, coffee creamers, ice cream, pasta products, cultured milk products, soups and gravies, whipped toppings, beverages, extruded snacks, and confectionary products. Whey protein products replace egg proteins in confectionary and bakery products and milk in ice cream and other dairy products. Different types of WPC and isolates can be produced by altering the processing parameters and techniques. Treatments that cause denaturation of whey proteins reduce the solubility, increase the water-holding capacity and viscosity, and improve the foaming characteristics of the whey protein products. However, different denaturation levels will produce products with varied characteristics. For example, excessive denaturation of whey proteins will have a detrimental effect on foaming properties. Whey protein concentrates and isolates as well as sodium caseinate have better emulsifying properties than the highly aggregated protein products such as calcium caseinate and micellar casein. Whey protein concentrates produce lower foam overruns but more stable foams than caseinates. The concentration of protein, $\mathrm{pH}$, content of other ingredients such as lactose and minerals, temperature, ionic strength, and $\mathrm{pH}$ are the most important factors affecting the gelation of whey proteins. The gelation properties of whey proteins increase their technological implications in the production of a variety of food products.

One of the most attractive applications of different ingredients from milk proteins is their use in the production of infant formula that resembles human milk. Enriching bovine milk with $\beta$-casein, $\alpha$-lactalbumin, and lactoferrin plus the physical separation of surplus components and $\alpha_{\mathrm{s}}$-casein from bovine milk have been reported to produce milk with a nutritional composition similar to that of human milk.

\section{Concentrated Milk Products}

Technology for traditional evaporated milk and concentrated milk products has not seen changes in the last $25 \mathrm{yr}$. Use of bulk condensed whole milk has declined from $1.2 \times 10^{5}$ tonnes to $5.9 \times 10^{4}$ tonnes; however, use of bulk condensed skim milk has grown moderately from $3.2 \times 10^{5}$ tonnes to $4.7 \times 10^{5}$ tonnes since 1981 .

Evaporated and concentrated milk products are manufactured using evaporative technology. The efficiency and capacity of the evaporators has increased substantially in the last $25 \mathrm{yr}$. Modern falling film evaporators are designed to take advantage of thermal vapor or mechanical vapor compression to reduce the requirement for steam in evaporating water from milk.

Production processes for evaporated or concentrated milk by membrane processes have been developed, but use on the industrial scale is limited. Concentration by RO would yield a product virtually identical in composition and properties to one undergoing concentration by evaporation. The use of the RO process allows the separation of water from milk without a phase change in such a manner that water is removed as liquid water permeate rather than as steam by evaporation installations.

Retail packaging for evaporated milk continues to be the traditional tinned can, although a layer of polymer coatings is usually applied to the cans to prevent dissolution of tin and iron in the milk product. These cans allow for in-container heating to kill all vegetative microbes and to inactivate bacterial spores. A variety of packaging materials such as aluminum foil-lined cartons, cups made of aluminum or polystyrene, and even translucent polystyrene portion control cups are used in aseptically packaging UHT-processed evaporated milk products.

\section{Milk Fat-Based Spreads}

Butter Consumption. In 2002, use of the United States' supply of milk fat to produce butter was over $14 \%$, which was only slightly below the amount $25 \mathrm{yr}$ earlier. The US per capita consumption of butter has remained at $2 \mathrm{~kg}(4.4 \mathrm{lb})$, which is similar to butter consumption in the early 1980s. This is interesting because butter has been the target of countless negative nutritional attacks centered on cholesterol, saturated fatty acids, fat, and calories.

A tremendous amount of research has been conducted with butter, milk-fat based spreads, and fractionated milk fat products over the past $25 \mathrm{yr}$. Milk fat has been modified and its unique properties have been studied; however, more research needs to be conducted to further increase knowledge of its beneficial constituents.

Fatty Acid Alteration. Feeding of protected fats to dairy cows allows fatty acids to be absorbed directly by the small intestine. Many protected fats are coated with formaldehyde/protein and therefore are not used in US dairy cattle rations. Several types of protected fat have been investigated; examples are tallow, coconut oil, safflower oil, and canola oil. Linoleic acid (C18:2) increased from its normal concentration of 2 to $3 \%$ in milk fat up to 30 to $35 \%$ when cows were fed protected fats. Butter produced from cows fed a canola-based protected lipid had no off-flavors and was found to have increased spreadability compared with conventional butter. As with protected fats, many sources of unprotected fats 
such as cottonseeds, soybeans, and sunflower seeds have been used in dairy cattle rations. When fed to dairy cows, unprotected fats higher in polyunsaturated fatty acids tend to produce milk fat with higher amounts of unsaturated fatty acids and lower amounts of saturated fatty acids, compared with feeding of more saturated fat sources. Generally, as unsaturation is increased, the susceptibility of fats to oxidation is increased. When cows were fed fats high in long-chain unsaturated fatty acids, the milk fat, and therefore butter manufactured from this milk, contained increased amounts of stearic (C18:0) and oleic acids (C18:1), whereas the amounts of short- and medium-chain fatty acids decreased. The butter produced from cows fed high oleic and regular sunflower seeds was softer, more unsaturated, and had acceptable flavor. A "mono-butter" was produced from milk from cows fed a diet containing full-fat rapeseed with $40 \%$ oleic acid (C18:1). This butter had superior spreadability compared with normal butter. When calcium salts of unsaturated fatty acids were added to dairy cow diets, the butter produced from the milk had improved thermal properties and was more spreadable from the refrigerator. The butter had less solid fat at $5^{\circ} \mathrm{C}$, but was similar to that in the control butter at $20^{\circ} \mathrm{C}$. A recent patent-pending feed supplement based on naturally occurring proteins in milk and other foods, has been reported to increase the proportion of unsaturated fatty acids (linolenic acid) as much as $800 \%$ in cows' milk. Other methods have been reported to physically modify butter to make it more spreadable at refrigeration temperatures for consumers. Mechanical working of butter, addition of surfactants, and incorporation of air have all been evaluated with limited success. Stepwise heating and cooling of cream before butter manufacture resulted in a butter that was softer and more spreadable.

Conjugated Linoleic and Transvaccenic Acids. Conjugated linoleic acid has received considerable attention due to its desirable human health benefits. Conjugated linoleic acid is a mixture of conjugated positional and geometric isomers of linoleic acid. Eight different CLA isomers are possible and the cis-9, trans11 isomer (rumenic acid) is believed to be the most biologically active. The cis-9, trans-11 isomer accounts for about $90 \%$ of the total CLA content in dairy products. Conjugated linoleic acid has been reported to have anticancer, antiatherogenic, antidiabetic, and antiobesity effects, as well as immune system enhancement. With all the positive benefits of CLA, research has focused on increasing its content in milk fat. Methods used to increase the CLA content include alteration of the cow's diet, use of supercritical carbon dioxide to alter fractions of milk fat, and interesterification of milk fat. Dairy products contain low levels of trans isomers of fatty acids, which have been implicated in raising human serum cholesterol levels. Trans fatty acid information is currently being considered for addition to food product nutritional labels. There has been interest in raising the concentration of transvaccenic acid (trans$11 \mathrm{C} 18: 1)$ in milk fat. In humans, transvaccenic acid is converted to CLA, a beneficial fatty acid. Although both CLA and transvaccenic acid are trans fatty acids, they should be considered beneficial to health, not detrimental. Butter with increased CLA, transvaccenic acid, and unsaturated fatty acid concentrations and having acceptable flavor has been produced by feeding fish oil and other lipids. Butter with enhanced CLA concentrations has been produced for use in biomedical studies with animal models. The possible inhibition of different types of cancer, as well as other health benefits, has been investigated by studying CLA in a naturally produced food product. In a rat model of breast cancer, butter with enhanced CLA concentrations was effective in reducing mammary cancer. A reduction in cells that cause colon cancer was reported in rats fed butter with enhanced CLA concentrations.

Butyric Acid. There has been interest in butyric acid (C4:0) as a potent anticancer agent in particular for colon cancer prevention. Butyric acid is present in milk fat at a level of more than $3 \%$. This is a unique feature of milk fat because no other common food contains this short-chain fatty acid. Research indicated that dietary butyric acid might also assist in cancer prevention at sites other than the colon. Increasing the butyric acid concentration in milk fat may develop into an important research area.

Cholesterol Reduction. A reduced-cholesterol milk fat produced by a steam-stripping method was used to manufacture reduced-cholesterol butter containing $85 \%$ less cholesterol than normal butter. Consumers indicated they would purchase the reduced-cholesterol butter at a premium price for home use as a spread. However, more recently, cholesterol has become less of an issue with consumers.

Fractionating Milk Fat. Separating milk fat into fractions offers opportunity to tailor ingredients to meet specific applications. Milk fat fractions have applications in improving butter spreadability, low-fat cheese texture, and chocolate meltability. Cold-spreadable butter could be manufactured by adding low-meltingpoint fractions to cream during the normal butter churning process. High-melting-point fractions can be used in UHT-recombined creams to increase creaming stability and to prevent chocolate from melting. Dry crystallization is a method used to fractionate milk fat. Anhydrous milk fat is heated, melted, cooled, and then stored under controlled conditions until crystallization is complete. A slurry of liquid milk fat and milk fat 
crystals is obtained and separated into low- and highmelting-point fractions. Melting points of the milk fat fractions can range from about 6 to $68^{\circ} \mathrm{C}$, whereas butter has a melting point of about $35^{\circ} \mathrm{C}$. However, the flavor of milk fat fractions does not differ.

Other Butters and Spreads. Organic butter is also being sold commercially, but comprises a small share of butter sales. Butter combined with vegetable oils (e.g., canola oil) has been developed to satisfy the need for a cold-spreadable product and is being sold commercially. Omega-3 (n-3) fatty acids are believed to reduce the risk of coronary heart disease, and play a role in the development and functioning of the nervous system and retina. Milk fat is low in omega- 3 fatty acids [eicosapentaenoic acid (C20:5), and docosahexaenoic acid (C22:6)]; however, fish oil is an excellent source of these fatty acids. Methods for increasing omega-3 fatty acids in milk fat have included incorporation of menhaden fish oil into the cows' diet. When blends of butter and vegetable oil containing a high concentration of omega3 fatty acids were evaluated for up to $6 \mathrm{wk}$, no adverse effect on flavor was observed. Development of butter and products high in omega-3 fatty acids needs careful evaluation, as these highly unsaturated fatty acids are susceptible to oxidation. Ghee (clarified butter) fed to Sprague-Dawley rats did not affect serum triglyceride or total cholesterol levels. However, when fed to Fischer (inbred) rats, serum triglyceride and total cholesterol levels increased. In humans, dietary ghee in moderate amounts may not affect blood lipids in the general population but may increase serum lipids in genetically predisposed individuals. Production of an ideal nutritional milk fat by altering fatty acid composition or other beneficial milk fat components would be desirable in a nutritional butter for consumers.

\section{REFERENCES}

Baer, R. J. 1991. Alteration of the fatty acid content of milk fat. J. Food Prot. 54:383-386.

Baer, R. J., J. Ryali, D. J. Schingoethe, K. M. Kasperson, D. C. Donovan, A. R. Hippen, and S. T. Franklin. 2001. Composition and properties of milk and butter from cows fed fish oil. J. Dairy Sci. 84:345-353.

Bauman, D. E., D. M. Barbano, D. A. Dwyer, and J. M. Griinari. 2000. Technical note: Production of butter with enhanced conjugated linoleic acid for use in biomedical studies with animal models. J. Dairy Sci. 83:2422-2425.

Bayourthe, C., F. Enjalbert, and R. Moncoulon. 2000. Effect of different forms of canola oil fatty acids plus canola meal on milk composition and physical properties of butter. J. Dairy Sci. 83:690-696.

Bobe, G., E. G. Hammond, A. E. Freeman, G. L. Lindberg, and D. C. Beitz. 2003. Texture of butter from cows with different milk fatty acid compositions. J. Dairy Sci. 86:3122-3127.

Cadden, A.-M., A. Urquhart, and P. Jelen. 1984. Evaluation of milk and butter from commercial dairy herds fed canola-based protected lipid feed supplement. J. Dairy Sci. 67:2041-2044.

Cadden, A.-M., A. Urquhart, and P. Jelen. 1984. Storage stability of canola-based protected lipid feed supplement and its effect on characteristics of milk and butter. J. Dairy Sci. 67:1414-1420.
Campos, R. J., J. W. Litwinenko, and A. G. Marangoni. 2003. Fractionation of milk fat by short-path distillation. J. Dairy Sci. 86:735-745.

Caric, M. 1994. Concentrated and dried dairy products. VCH Publisher, New York, NY.

Cheryan, M. 1998. Ultrafiltration and Microfiltration Handbook. Technomic Publishing Company, Lancaster, PA.

Chouinard, P. Y., L. Corneau, W. R. Butler, Y. Chilliard, J. K. Drackley, and D. E. Bauman. 2001. Effect of dietary lipid source on conjugated linoleic acid concentrations in milk fat. J. Dairy Sci. 84:680-690.

Chouinard, P. Y., V. Girard, and G. J. Brisson. 1998. Fatty acid profile and physical properties of milk fat from cows fed calcium salts of fatty acids with varying unsaturation. J. Dairy Sci. 81:471-481.

De Wit, J. N. 1998. Nutritional and functional characteristics of whey proteins in food products. J. Dairy Sci. 81:597-608.

Dhiman, T. R., G. R. Anand, L. D. Satter, and M. W. Pariza. 1999. Conjugated linoleic acid content of milk from cows fed different diets. J. Dairy Sci. 82:2146-2156.

Dhiman, T. R., L. D. Satter, M. W. Pariza, M. P. Galli, K. Albright, and M. X. Tolosa. 2000. Conjugated linoleic acid (CLA) content of milk from cows offered diets rich in linoleic and linolenic acid. J. Dairy Sci. 83:1016-1027.

Dwivedi, C., V. V. Mistry, H. M. Sharma, and A. E. Crosser. 2002. Effects of dietary ghee (clarified butter) on serum lipids in rats. J. Appl. Nutr. 52:64-68.

Enjalbert, F., M. C. Nicot, C. Bayourthe, and R. Moncoulon. 2000. Effects of duodenal infusions of palmitic, stearic, or oleic acids on milk composition and physical properties of butter. J. Dairy Sci. 83:1428-1433.

Ernstrom, C. A., R. J. Sutherland, and G. W. Jameson. 1980. Cheese base for processing of high yield product from whole milk by ultrafiltration. J. Dairy Sci. 63:228-234.

Fox, P. F., T. P. O'Connor, P. L. H. McSweeney, T. P. Guinee, and N. M. O'Brien. 1996. Cheese: Physical, biochemical, and nutritional aspects. Adv. Food Nutr. Res. 39:163-328.

Garcia, H. S., K. J. Keough, J. A. Arcos, and C. G. Hill, Jr. 2000. Interesterification (acidolysis) of butterfat with conjugated linoleic acid in a batch reactor. J. Dairy Sci. 83:371-377.

Gnadig, S. 2002. Conjugated linoleic acid (CLA): Effect of processing on CLA in cheese and the impact of CLA on the arachidonic acid metabolism. PhD Diss., University of Hamburg, Germany.

Gonzalez, S., S. E. Duncan, S. F. O'Keefe, S. S. Sumner, and J. H. Herbein. 2003. Oxidation and textural characteristics of butter and ice cream with modified fatty acid profiles. J. Dairy Sci. 86:70-77.

Goudedranche, H., J. Fauquant, and J.-L. Maubois. 2000. Fractionation of globular milk fat by membrane microfiltration. Lait 80:93-98.

Haileselassie, S. S., B. H. Lee, and B. F. Gibbs. 1999. Purification and identification of potentially bioactive peptides from enzyme modified cheese. J. Dairy Sci. 82:1612-1617.

Hillbrick, M., and M. A. Augustin. 2002. Milk fat characteristics and functionality: Opportunities for improvement. Aust. J. Dairy Technol. 57:45-51.

Hurwitz, M. F. 2000. Shear separation: A promising method for protein fractionation. Lait 80:121-127.

International Dairy Foods Association. 2003. Pages 26 and 117 in Dairy Facts. International Dairy Foods Assoc., Washington, DC.

Jimenez-Flores, R. 1997. Trends in research for alternate uses of milk fat. J. Dairy Sci. 80:2644-2650.

Jones, D. F., W. P. Weiss, and D. L. Palmquist. 2000. Short Communication: Influence of dietary tallow and fish oil on milk fat composition. J. Dairy Sci. 83:2024-2026.

Kaylegian, K. E. 1999. The production of specialty milk fat ingredients. J. Dairy Sci. 82:1433-1439.

Kaylegian, K. E., and R. C. Lindsay. 1992. Performance of selected milk fat fractions in cold-spreadable butter. J. Dairy Sci. 75:3307-3317.

Kelsey, J. A., B. A. Corl, R. J. Collier, and D. E. Bauman. 2003. The effect of breed, parity, and stage of lactation on conjugated linoleic acid (CLA) in milk fat from dairy cows. J. Dairy Sci. 86:2588-2597. 
Kleyn, D. H. 1992. Textural aspects of butter. Food Technol. 46:118-121.

Kosikowski, F. V., and V. V. Mistry. 1997. Cheese and fermented milk foods. Vol. I. Origins and principles. F. V. Kosikowski, LLC, Westport, CT.

Lin, H., T. D. Boylston, M. J. Chang, L. O. Luedecke, and T. D. Shultz. 1995. Survey of the conjugated linoleic acid contents of dairy products. J. Dairy Sci. 78:2358-2365.

Lucey, J. A., M. E. Johnson, and D. S. Horne. 2003. Invited review: Perspectives on the basis of the rheology and texture properties of cheese. J. Dairy Sci. 86:2725-2743.

Mann, E. 2001. Processed cheese and cheese analogues. Dairy Ind Int. $66: 37-38$.

Mann, E. 2002. Butter-Part one. Dairy Ind. Int. 67:35-36.

Mann, E. 2002. Butter and butter-related spreads-Part two. Dairy Ind. Int. 67:31-32.

Mann, E. 2002. Cheddar cheese. Dairy Ind. Int.. 67:35-36.

Mann, E. J. 1990. Modified butters and spreads. Dairy Ind. Int. $55: 9,11$.

Maubois, J.-L., and G. Mocquot. 1984. Application of membrane ultrafiltration to preparations of various types of cheese. J. Dairy Sci. 58:1001-1007.

Maubois, J.-L., and P. Schuck. 2002. First International Symposium on Spray Drying of Milk Products. October 16-18, 2002. Rennes Cedex, France. Lait 82:371-551.

Middaugh, R. P., R. J. Baer, D. P. Casper, D. J. Schingoethe, and S. W. Seas. 1988. Characteristics of milk and butter from cows fed sunflower seeds. J. Dairy Sci. 71:3179-3187.

Murphy, J. J. 1992. Altering the composition of milk fat by dietary means. Irish Grassl. Anim. Prod. J. 25:3-7.

O’Donnell, J. 1990. Research unlocks milkfat secrets. Dairy Foods 90:93-94.

O'Donnell, J. A. 1989. Milk fat technologies and markets: A summary of the Wisconsin Milk Marketing Board 1988 Milk Fat Roundtable. J. Dairy Sci. 72:3109-3115.

Parodi, P. W. 2003. Anti-cancer agents in milkfat. Aust. J. Dairy Technol. 58:114-118.

Pisecky, J. 1997. Handbook of milk powder manufacture. Niro A/S, Copenhagen, Denmark.

Precht, D., and J. Molkentin. 1997. Effect on feeding on trans positional isomers of octadecenoic acid in milk fats. Milchwissenschaft $52: 564-568$

Ramaswamy, N., R. J. Baer, D. J. Schingoethe, A. R. Hippen, K. M. Kasperson, and L. A. Whitlock. 2001. Composition and flavor of milk and butter from cows fed fish oil, extruded soybeans, or their combination. J. Dairy Sci. 84:2144-2151.
Renner, E., and M. H. Abd El-Salam. 1991. Application of ultrafiltration in the dairy industry. Elsevier Appl. Sci., New York, NY.

Robinson, R. K. 1986. Modern Dairy Technology. Vol. I. Advances in Milk Processing. Elsevier Appl. Sci., New York, NY.

Rogers, W. P., and F. G. Kieseker. 1985. Observations on the manufacture of recombined butter. Aust. J. Dairy Technol. 40:157-163.

Roginski, H., J. Fuquay, and P. F. Fox. 2003. Encyclopedia of Dairy Sciences. Academic Press, London, UK.

Santora, J. E., D. L. Palmquist, and K. L. Roehrig. 2000. Transvaccenic acid is desaturated to conjugated linoleic acid in mice. J. Nutr. 130:208-215.

Schaffer, B., S. Szakaly, D. Lorinczy, and J. Belagyi. 1999. Structure of butter. III. Effect of modification of cream ripening and fatty acid composition on the melting properties of butter fat. Milchwissenschaft 54:82-85.

Schaffer, B., S. Szakaly, D. Lorinczy, and J. Belagyi. 2000. Structure of butter. IV. Effect of modification of cream ripening and fatty acid composition on the consistency of butter. Milchwissenschaft 55:132-135.

Schroder, B. G., and R. J. Baer. 1991. Consumer evaluation of reduced-cholesterol butter. Food Technol. 45:104-107.

Scott, L. L., S. E. Duncan, S. S. Sumner, and K. M. Waterman. 2003. Physical properties of cream reformulated with fractionated milk fat and milk-derived components. J. Dairy Sci. 86:3395-3404.

Shiota, M., H. Konishi, and K. Tatsumi. 1999. Oxidative stability of fish oil blended with butter. J. Dairy Sci. 82:1877-1881.

Shukla, A., A. R. Bhaskar, S. S. H. Rizvi, and S. J. Mulvaney. 1994. Physicochemical and rheological properties of butter made from supercritically fractionated milk fat. J. Dairy Sci. 77:45-54.

Shukla, A., and S. S. H. Rizvi. 1996. Relationship among chemical composition, microstructure and rheological properties of butter. Milchwissenschaft 51:144-148.

Sporns, P., J. Rebolledo, A.-M. Cadden, and P. Jelen. 1984. Compositional changes in fatty acids of butter caused by feeding canolabased protected lipid feed supplement. Milchwissenschaft 39:330-332.

Stegeman, G. A., R. J. Baer, D. J. Schingoethe, and D. P. Casper. 1992. Composition and flavor of milk and butter from cows fed unsaturated dietary fat and receiving bovine somatotropin. J. Dairy Sci. 75:962-970.

Urquhart, A., A. M. Cadden, and P. Jelen. 1984. Quality of milk and butter related to canola-based protected lipid feed supplement. Milchwissenschaft 39:1-6.

Wong, W., P. Jelen, and J. M. DeMan. 1982. Softening of butter related to feeding low doses of protected-tallow supplement. J. Dairy Sci. 65:1632-1638. 